\title{
Towards A True Afropolitanism: Reconstructing African Diasporic Identities
}

\author{
Chike Mgbeadichie \& Chike Okoye \\ https://dx.doi.org/10.4314/ujah.v22i2.1
}

\section{Abstract}

This essay redefines the idea of Afropolitanism lost in the world of identity and cultural studies. Defined by Taiye Selasi as a concept that studies persons of African descent who found home everywhere they lived, yet belonged nowhere, this paper holds an opposing view to this interpretation of Afropolitans. We argue that Afropolitans are African diaspora who are (un)consciously slanted to their root in a specific manner; they belong somewhere and the construction and reconstruction of their identity are tied to their root. To re-theorize Afropolitanism in this manner, this research examines Michael Kerr's idea of the post-modern self, showing a comparative account of the pseudo-self and the solid-self, in relation to the Afropolitan identity construction. The reinterpretation of James Clifford's position on place and space and the examination of Cecil Blake's ideology of belonging, root, and routes, are critical to my re-reading of the Afropolitan vibe. Although derived from theories of cultural hybridity, transnationalism, cosmopolitanism, and elective affinity, this paper demystifies Afropolitanism by showing how it differs remarkably from these theories in analyzing the underlying questions of African identity and lived experience. Whilst lived experiences of African diaspora constitute part of the existence of the Afropolitan, we argue that the construction of the Afropolitan identity is not reliant on an acquired identity or lived experience but an ascribed identity and root. Okey Ndibe's Never Look an American in the 
Eyes, will serve as the primary text for this analysis, and we conclude this research by articulating how Ndibe and other Afropolitan novelists manipulate culture, language, and race to reflect our position on Afropolitanism.

\section{Keywords: Afropolitanism; African culture; Root; Routes; Diasporic identity; African identity}

\section{Introduction}

Before the $21^{\text {st }}$ century, many theories have been carefully followed on how to reconstruct and recreate the already broken identities of Africans after the calamities of slavery and its attendant structures. Whilst most discourses like Post-colonialism, Afrocentrism, and Negritude amongst others capture the representation of Africans before and immediately after the era of colonialism and slavery, few conjectures have shifted gaze to concentrate on modern Africans who are plagued with the obsession of migration out of Africa. In the wake of the monumental struggle for migration out of Africa in search of greener pastures by many Africans, more attention has been given to examining the reasons for such quotidian activity of the new Africans- people who are constantly seeking opportunities out of Africa to develop their capacity, resources, experience, and culture. The debate has extended not just on the perspicuous reasons for their migration, but on the crosscultural exchanges between the African culture and the new culture, in view to adequately address the immediate challenge of cultural displacement and identity crisis encountered by these Africans 
Understandably, therefore, the present concern of many African critics is no longer the struggle of identity construction by dealing with the immediate legacy of colonialism coupled with slavery, and as Charles Nnolim puts it in a forward to Sophia Akhuemokhan's critical piece, 'to enter the battle field to fight the white man from within' since colonial trajectories have been overtaken by a stiffer problem in Africa, but a revolutionary need to reconstruct the identity of African migrants who have 'crossed the Mediterranean to France, England, Spain, Germany' and should we add, the United States of America (Akhuemokhan 2014: IX). Whilst the fulcrum of postcolonial critics is on the construction of African identities within Africa -challenging the damaged reputation of Africans in Africa-, the Afropolitan analysts are championing a new course of African identity re-construction out of Africa, by taking a critical look on modern Africans and their migratory experiences. We are not advocating an end to colonial discourses and debates. What we are suggesting is that Afropolitanism holds a prominent position in the discourse of the $21^{\text {st }}$ century Africa's identity re-construction and should be given more focus. Regardless, one must stress that the theory of Afropolitanism cannot be completely detached from the debate on colonialism since the identity struggle of Africans in the diaspora could be argued as part of the unresolved legacies of colonialism. After all, the Igbo proverb, made popular by Chinua Achebe, admonishes that, 'a man who cannot tell where the rain began to beat him cannot know where he dried his body' (Achebe 1964: 3). In resolving this current challenge of Africans in the diaspora, many Afropolitan scholars have engaged the theory from diverse points of view. Whilst some (Eze 2014: 240) equate Afropolitanism with cosmopolitanism and hybridity, advocating a sense of culture hybrid and the expansion of the identity of Africans 
beyond a single model as the solution to Africa's identity reconstruction, others (Yazdiha 2010: 31) conceive Afropolitanism as the idea of fluidity and ambiguity, arguing that Africa's socially ascribed identities are erased by the deeper connections, lived experiences, interactions and in short, the acquired identities of African migrants in their new communities.

As a result of such contrasting and confusing notions on Afropolitanism, and the conscious obliteration of the African root in resolving the identity crisis of the Afropolitans, this paper seeks to redefine the Afropolitans. We argue that Afropolitans are African diaspora who are consciously or unconsciously slanted to their root in a specific manner; they belong somewhere and the construction and reconstruction of their identity are tied to their root. To re-theorize Afropolitanism in this manner, this research examines Michael Kerr's idea of the post-modern self, showing a comparative account of the pseudo-self and the solid-self in relation to the Afropolitan identity construction. The re-interpretation of James Clifford's position on place and space and the examination of Cecil Blake's ideology of belonging, root, and routes, are critical to our re-reading of the Afropolitan vibe. Although derived from theories of cultural hybridity, transnationalism, cosmopolitanism, and elective affinity, this paper demystifies Afropolitanism by showing how it differs remarkably from these theories in analyzing the underlying questions of African identity and lived experience. Whilst lived experiences of African diaspora constitute part of the existence of the Afropolitan, we argue that the construction of the Afropolitan identity is not reliant on acquired identity or lived experience but ascribed identity and root. The literary focus for this study is Okey Ndibe's non-fiction: Never Look an American 
in the Eye, and we conclude this research by articulating how Ndibe and other Afropolitan novelists manipulate culture, language, and race to reflect my position on Afropolitanism.

\section{Okey Ndibe: The Afropolitan Voice}

Born October 1, 1960, Nigeria's Independence Day, in Yola, Nigeria, Okey Ndibe is a well-known essayist, columnist, critic, and novelist from the Igbo extraction, whose prowess in criticism and literature was greatly influenced by the trio of Chinua Achebe, Wole Soyinka, and Ngugi wa Thiong'o. He lays claim to a solid relationship with these three acclaimed African best writers in his memoir, Never Look an American in the Eyes. From the episodes, 'Lying to Be a Writer' where he narrates his meeting with Ngugi wa Thiong'o and expresses that both of them began their writing careers by lying to be writers; to 'Wole Soyinka Saves My Christmas' where he shows the heavy role Soyinka played in his early days in the US; and 'English Dreams, Communist Fantasies, and American Wrestling' detailing his first meeting with Chinua Achebe which opened opportunities for him and ultimately led to his travel to the US, Ndibe celebrates and pours great encomiums on these writers. He began his career as a newspaper columnist and journalist with a strong focus on social commitment, advocating for the peasant and poor of Nigeria. He is a regular writer for The Hartford Courant, the oldest continuously published newspaper in the US, Next, and several others. His editorial pieces have won several awards. His first novel, Arrows of Rain was published in 2000 and his second, Foreign Gods, Inc., 2014, according to The New York Times, was one of the best books of 2014. He is also the author of the 2017 Afropolitan non-fiction and memoir, Never Look an American in the Eye. Ndibe has taught at Brown University and several other US colleges and was a Fulbright lecturer at the 
University of Lagos. In 2015-2016, he was a Black Mountain Institute (BMI) fellow at the University of Nevada, Las Vegas. He is at the moment working on another novel, Native Tongues.

Of all Ndibe's published stories, Never Look an American in the Eye is considered his best not because it is a non-fiction that details his life and time in a foreign land, but for the message, style, content, 'boisterous, almost raucous tale of youthful fantasies, [... ] [the] social transformation, intellectual sagacity, [and] courage in the face of mounting odds' (Emeyonu 2017). This novel is a typical Afropolitan piece that captures Ndibe's personal story and his migratory experience to the US. Broken into eighteen fascinating episodes, we read as 'the trajectory of a migrant's life follows a well cut-out template. There is the shock, the adjustment and then the transformation' (Okonkwo 2018). Within the novel are clear Afropolitan challenges of alienation, displacement, and identity crisis and the Afropolitan's wish for hope, cultural identity, and redemption. What puts this novel in a class of its own, Ernest Emeyonu (2017) contends, 'is the author's inimitable craftsmanship- a skillful blending of an ace journalist's audacious integrity, with the imaginative wizardry of a creative genius.' In the novel, Ndibe returns to his passion for proper story-telling, employing the journalistic reportage style to create, re-create and uncover the experiences of the Afropolitans. He gives a detailed account of his life as a young journalist in Nigeria, his meeting with Chinua Achebe, and his travel to the US with the travails of the African migrants in the acquisition of the American identity.

Although scant critical work has been done on this novel because it is fairly new, Ndibe's Afropolitan story has been appraised by some writers and literary critics. Joshua Wolf (2017) 
writes that 'Okey Ndibe is a natural raconteur, and his tales of coming to America are winsome and lyrical and absorbing. But within lies a larger narrative: about the education of a new American- and a writer's power to span continents in his imagination.' The Booklist (2017) reviewed this novel as a 'moving and often laugh-out-loud account of one man's immigrant experience.' The West Hartford News (2017) sees it as 'a generous, encompassing book about the making of a writer and a new American.' The compelling nature, 'spell chivalry and triumph in the memoir', and the truthful treatment of materials could be heavily linked to the journalistic style of the novel. For Ndibe, as he puts it in an interview with Syncity $N G$ (2018), 'journalism teaches many useful skills to the fiction [and non-fiction] writer. Many novelists- Gabriel Garcia Marquez, Chinua Achebe, Cyprain Ekwuensi, to name a few- started in journalism. The profession cultivates economy of expression and a sense of what's at stake.' What is at stake now is the question of the identity of the Afropolitan, and this is a leitmotif in Ndibe's novels.

We have chosen Ndibe's non-fiction rather than his fiction or any other fictional novel by a different writer for some reason. First, despite the few exaggerations and fictional spices in the novel, the episodic stories are truthful, clear, and accurate. Second, 'his mesmeric unraveling of the intricacies of [the Afropolitans'] spoken and unspoken behavior, mannerisms, and nuances' (Emeyonu 2017), help our re-reading of Afropolitanism. Third, the language is in its highest 'dexterity, irony at its ultimate sophistication, and wisdom at its most delectable height' (Emeyonu 2017). Fourthly and lastly, there is the presence of a voice of hope for redemption which provides support and encouragement for the Afropolitans as opposed to the usual nostalgic voice of fear replete in many Afropolitan novels. We believe this memoir provides as 
much nuance, if not better than other novels, in the interpretation and re-thinking of the Afropolitan agenda.

\section{Defining Afropolitanism}

The word 'Afropolitan' was popularised by Taiye Selasi, a Britishborn child of Nigerian and Ghanaian parents, in her 2005 essay, 'Bye-Bye Babar', where she captures the harsh realities of African diasporas within the context of acceptance, citizenship, and homeland. To define who an Afropolitan is, she describes a scene at a bar in London filled with people whom she calls 'Afropolitan' for the reason of their appearance, style of talk, and choice of music:

The whole scene speaks of the Cultural Hybrid: kente cloth worn over low-waisted jeans; 'African lady' over Ludacris bass lines; London meets Lagos meets Durban meets Dakar... were you to ask any of these beautiful, brown-skinned people that basic question- 'where are you from?'- you'd get no single answer from a single smiling dancer. This one lives in London but was raised in Toronto and born in Accra; that one works in Lagos but grew up in Houston, Texas.... They are Afropolitans- the newest generation of African emigrants... (they) are Afropolitan: not citizens, but Africans of the world. (Selasi 2005:2)

What is fascinating in Selasi's account is her portrayal of the Afropolitans as displaced persons who found home everywhere they lived, yet truly belonged nowhere. In her opinion, to live in London, be raised in Toronto, and be born in Accra is to be completely dislocated from the British, Canadian, and Ghanaian 
cultures. Hence, as she argues, such Afropolitan is not a citizen of any of these countries, but a mere African traversing the globe. Isn't this problematic and contradictory that one can be a mere African and not be a citizen of an African country? Selasi's representation of the new generation African immigrant in this way does not fully integrate or locate the Afropolitan in specific cultures, not even the African culture. She is aptly captured by Arianna Dagnino's echo of Zygmunt Bauman's suggestion about “an age of 'global uncertainty' and 'liquid times' in which fixed points of reference vanish, boundaries fade, cultural edges blur, and ... (there is) movement, and voluntary or involuntary displacement..." (Dagnino 2015:99); or even more concisely by Bauman: "shifty and unpredictable, they have no tie to any place" (Bauman 2007:48). In identifying herself, Selasi, born in Britain by Nigerian and Ghanaian parents, refuses to be called African; she defined herself instead as Afropolitan. But how can one talk of an Afropolitan without reference to his race, regional background, and the realities of colonial legacies?

Selasi no doubt contradicts herself when she acknowledges and positions Afropolitan within the African culture through reference to their dance, dress sense, and manners. Even though she argues that Afropolitans have little knowledge and are not fully accepted and integrated into their ancestral nations at their return, there is no denying the fact that they have an ancestral root, a heritage, a background, and a place. It is interesting to note that Selasi, in her interpretation of the Afropolitan principle, does not use the term 'root'. She replaced it with 'link', arguing that, Afropolitans are 'multi-locals' with no fixed root anywhere but are linked to multi-cultures and locations because of their constant migration in search of educational opportunities, economic advantages, and fleeing wars and political tensions. Even though 
one understands that the present realities in Africa encourage migration out of Africa thereby providing Afropolitan with different experiences, identities, and cultures, Selasi argues that Afropolitans have identities that are mobile with no 'root' in Africa, which is problematic. We contend that, despite the constant migrations out of Africa, there is always an ultimate return to the African root and 'to knowable African communities, nations, and traditions' (Wawrzinek 2010:12).

Defined, we conceive the Afropolitans as African diaspora who are consciously or unconsciously slanted to their root in a specific manner. The root is important in our reading of Afropolitanism and our decision to relate the Afropolitans as diasporas is consequent of the detailed definition of the diasporas by William Safran who defined diasporas as:

expatriate minority communities (1) that are dispersed from an original centre to at least two peripheral places; (2) that maintain a memory, vision, or myth about their original homeland; (3) that believe they are not- and perhaps cannot be- fully accepted by their host country; (4) that see the ancestral home as a place of eventual return, when the time is right; (5) that are committed to the maintenance or restoration of this homeland; and (6) whose consciousness and solidarity as a group is 'importantly defined' by this continuing relationship with the homeland (Safran 1991: 83-84).

What we take from this clear definition is the importance of roots and heritage for the African migrant. We strongly disagree 
with Selasi and others who argue that disaporas like Afropolitans 'are not always oriented to their roots in a specific place. They more and more re-create a culture in new diverse locations' (Lie 2000:13). To re-create their culture in these locations, they would need to first embrace and accept their root and heritage. Accepting one's heritage opens up liminal spaces in one's mind to re-create such culture in their host country. Such an act, we argue, is a calculated attempt to constantly put their ascribed tradition in their subconscious; it does not in any way erase or diminish their love for their root. We will stress this point later. Although many might argue that Selasi's reading of Afropolitanism in this way is a bit problematic, there is no doubt that she has provided a space to understand the complex identity crisis of African diasporas and has begun a necessary conversation on the reconstruction of African identity within a broad spectrum.

Other "isms" akin to migration and diasporic tensions create a backdrop that makes a case for better comprehension and also considers the relationship(s) of static roots and their dispersal(s) through the migrant. One of these, the postmodern concept of transculturalism, has been described by Yolanda Onghena as "the product of a meeting between an existing culture or subculture and a migrant, recently arrived, which transforms the two and creates in the process a neo culture, which is also subject to transculturation" (Onghena 2017:182). The concept which is interestingly described by Donald Cuccioletta as "seeing oneself in the other", differs from multiculturalism which is all about boundaries which exist to concretize the "cultural essences of nation-states as individually distinct from one another" (Okoye 2017:59). Interculturality weighs in here as a somewhat short-lived period of peaceable and tranquil co-existence of at least two cultures as a false impression, while cloaked tensions of 
antagonism simmer beneath. All these litter the existential path of, and exert influence on, the Afropolitan. Their relationship and uniqueness are succinctly summarized thus:

In other words, as multiculturalism emphasizes the right to be different, interculturality presents a somewhat peaceful co-existence (all between cultures); while transculturalism suggests and operates in such a way as to produce a hybridized but new and independent culture from a mixture and alteration of existing cultures that have made contact. (Okoye 2017:60)

The Afropolitan, we contend, cannot be categorized as rootless. They have a 'fixed or stable collective history, in which they are affiliated to the [African] race or ethnicity (Hall 1994:402). From Selasi's description of the people in the bar, it is evident that these people, as Stuart Hall argues, have a 'shared culture, a sort of collective "one true self..." [their] cultural identities reflect the common historical experiences and shared cultural codes which provide [them] as "one people", with stable, unchanging, and continuous frames of reference and meaning, beneath the shifting divisions and vicissitudes of [their] actual history' (Hall 1994:403). These people, no doubt, have a shared African root and collective history. They have an ascribed culture which Paul Gilroy in The Black Atlantic argues is reflected through the African tradition. It is however through this tradition that these Afropolitans 'demonstrate the continuity of selected contemporary phenomena with an African past that shaped them' (Gilroy 1999:34). Hence, with the migration to a foreign place and with a shift in cultural position in search for acquired identity, 'they no longer recognize 
[their tradition] and only slightly resembles [it]' (Gilroy 1999:34). That the Afropolitan chooses not to identify with and recognize their African tradition does not mean they do not have a root nor belong somewhere, neither does it stripe them of their African citizenship. We argue that once a migrant can trace his heritage to Africa, no matter how long it takes and despite his choice 'to no longer recognize' his tradition, his identity is shaped by his heritage. He can only struggle to reject his heritage but in the end, at one point or the other, he would recognize and own his root. Julius, the protagonist in Teju Cole's Open City, fits this narrative. Julius' eventual return and acceptance of the Nigerian culture, despite several years abroad, and after an outright rejection of his Nigerianness, suggests that a migrant's acquired identity cannot completely erase his ascribed identity.

Similar to Selasi's argument, Achille Mbembe, in his 2007 essay, 'Afropolitanism', tries to dismantle the idea of the African root in his conception of the Afropolitan idea. Summarized by Balakrishnan, Mbembe argues that, 'the meaning of being African had to be dislodged from race, nativist traditions and be opened to the flows of global networks and worldly hybridity' (Balakrishnan 2017:7). Afropolitanism for Mbembe is an idea that is not rooted in the African tradition but based on plural, multiple and openended cultures. He contends that African philosophers will continue to be inferior and not be universal if they do not step aside and step outside their cultural heritage in their thinking of Afropolitanism. We question such interpretation of Afropolitanism because it has reduced the essence of the African heritage in the formation of the Afropolitan identity and has equated Afropolitanism as cosmopolitanism.

The Afropolitans, Wawrzinek, and Makokha argue, are 'Africans at home and abroad who subscribe to anti-nativist and 
[promote] cosmopolitan interpretations of African identities' (Wawrzinek 2011:21). To view the Afropolitans within this framework is to fulfill Selasi's analysis above. Such reading and argument against the return to the African native culture as the essentialist interpretation of the Afropolitan discourse distort and complicates the identity narrative of Africans, denying them of their ascribed heritage and root, and muddling who they are, what they are, and where they come from. To find a permanent solution to a problem, one must go to the 'root' of that problem, not a 'link' to the problem. In the same vein, to resolve the identity crisis of the Afropolitan and to recreate their sense of self, person, and worth, the very first port of call should be to the African root and heritage. Afropolitanism therefore should advocate a return and trace to the African heritage, not championing a call for erasing it, and making the Afropolitan a cosmopolitan with no fixed identity.

Eze sees the Afropolitan as 'that human being on the African continent or of African descent who has realized that her identity can no longer be explained in purist, essentialist, and oppositional terms or by reference only to Africa' (Eze 2014:240). The Afropolitans, he continues, 'are no longer just $\mathrm{X}$ as opposed to Y; rather they are A and B and X' (Eze 2014:240). Whilst agreeing that there is some sense of cultural connectivity, duality, and hybridity occasioned by the Afropolitan experience, we disagree with Eze when he argues further that, given this culture mix, 'it is impossible [for the Afropolitans] to go back to their native place since they are all mutts, biologically or culturally' (Eze 2014:241). All contemporary Afropolitans have an idea of their ancestral country; some only choose not to affiliate themselves with the country. In Teju Cole's Afropolitan novel, Open City, Cole 
presents the protagonist, Julius, a young man, who rejects his Nigerian ancestral home. Although Julius knows his root, he struggles at first to disconnect himself from any attempted association with Nigerians. In his opinion, 'birth, race, or family [should not] entail ethical obligation' (Cole 2011:30). In the end, he is unable to keep a distance from his root. His later actions indicate that he recognizes that he shares cultural identity with Nigerian and African diasporas. Chimamanda Adichie's Ifemelu in Americanah, another Afropolitan novel, refutes the claims of Eze by her constant reference and eventual return to Nigeria, after many years in the United States of America. In Never Look an American in the Eye, Ndibe rebuffs Eze's argument when he (Ndibe) refused to completely give up filial ties with his ancestral home, Nigeria, despite the many challenges and pressures to jettison his Nigerianness for the American culture whilst in America. As will be well explored in subsequent pages of this paper, these texts, particularly Ndibe's, will be interpreted to show that, despite being 'mutts', the Afropolitans have a root and it is very possible for them to go back to their native place.

\section{The Afropolitan Self}

Articulating the postmodern self is a critical position to reshaping the Afropolitan identity. It is the self that controls the position of a person, and a person's position ultimately determines his identity. The self as will be used in this paper refers to the mental perception of how someone thinks about, evaluates, perceives, or is aware of his identity as a human. The postmodern Afropolitan self can be better understood along two clear lines: the solid-self and the pseudo-self.

In Chronic Anxiety and Defining a Self, Michael Kerr espouses that the pseudo-self refers to knowledge and beliefs 
acquired from others which are incorporated by the intellect and negotiable in relationships with others (Kerr 1988:44). The pseudo-self lacks the strength to define himself but relies on his relationships with others to acquire a self. They are created by emotional pressures and can be modified by such pressures. They change beliefs to enhance their image with others when confronted with identity crises and emotional pressures. In short, they are not true to themselves. This is the type of 'self' of many Afropolitans who, in the face of mounting pressure for survival, reject the African way of life and embrace the beliefs of their host country for acceptance in the foreign land. What this shows is that these people are not true to themselves. They pretend to love the lifestyle and beliefs of their host country, while in an actual sense, it is a strategy for acceptance and survival. Kerr captures this more accurately- 'the pseudo-self is a pretend self' (Kerr 1988:46). Given the need for acceptance and assimilation, this category of Afropolitans pretend to be who they are not- 'they pretend to be more or less important than they are, stronger or weaker than they really are, more or less attractive than they really are' (Kerr 1988:31) and happy or sad about the attitudes of the people in the host nation. Such 'self' is a complete package of falsehood, pretense, and lies; and because many Afropolitan identities have been built on this false-self, it suggests the puzzling recurrent challenge of identity crisis witnessed by the Afropolitans. Falseself is a major challenge for the present day Afropolitan. Victor Gecas, a sociologist who studied the concept of self, argues that 'being true to oneself, or even knowing oneself, has become increasingly problematic in modern times' (Gecas 1982: 5). Having a pseudo-self as an Afropolitan who compromises his 
African root for foreign acceptance, puts such a migrant in a much more difficult position in matters of identity construction. Whilst it is agreed that pressure for conformity can cause the intellectual principle of self to be compromised, the African migrant is encouraged to hold firm his ascribed identity which is permanent, because, once an ascribed self is broken, it is difficult to reconstruct.

In Never Look an American in the Eye, Ndibe begins his narration by describing his strong love and interest for the United States of America:

America sneaked up on me, announced itself in my dreams, and made a claim for my attention I was powerless to resist... It was its mixture of swashbuckling drama and flair for evocative names that compelled my attention... their wrestlers had names like Jimmy 'Superfly' Snuka, Ricky 'the Dragon' Steamboat, Ernie Ladd... 'Nature Boy' Buddy Rogers, Terry Funk, ... I marveled at the drop kicks, pile drives, body slams, head butts, figure-four leg locks, and a variety of submission holds. The wrestlers had to be a different breed of men, specimens grown on some human farm, their bodies steel-like. It stirred something within me, a desire to see America, the country that produced these elephantine beings. As I paid attention to America, I became fascinated by the names of its actors, its cities, and states. In my secondary school days, a kind of gum was in vogue. Each pack of gum came with a small card that bore the name of an American actor... One day, I unveiled a card with the photo and name of Tony Curtis... My parents had 
named me Anthony, after Saint Anthony of Padua. The moment I saw the card, I renamed myself Tony Curtis (Ndibe 2017:13-14).

What Ndibe describes in this manner and the subsequent episodes that followed suggest that Ndibe began his Afropolitan journey as a pseudo-self. His dream and desire to be American trumps his interest in his local beliefs and practices. In many instances in the novel, just like the one captured above, he transposes his real self to Tony Curtis, an American actor. By this single act, he rejects his African identity and takes on a different one, that of the American. As a pseudo-self who lives on pretense and has a false identity, Ndibe pretends to be an American actor, wrestler, and musician which only provides, as he says, a temporary 'swagger that went with a wild awakening interest in girls' and a strong reputation that soon vanished into thin air (Ndibe 2017:13). The pseudo-self is a temporal identity that is occasioned by human social demands for acceptance. The reading of Adichie's Ifemelu in Americana justifies this argument. Ifemelu left Nigeria full of pride with her Afro-kinky hair. Whilst in Nigeria, women saw beauty and pride in keeping and maintaining their Afro-kinky hair. However, in America, a woman's hair is considered beautiful only when it is straightened. Due to social pressure and the need to be accepted into American society, Ifemelu conforms to the American hairstyle and straightened her hair. At this point, she displays, just like Ndibe, a pseudo-self. But not long had she straightened her hair like the Americans, did she reject such style and return to keeping her Afro-kinky hair. She returns to wearing her hair naturally in an Afro. She even turns to the internet for help to better 
care for her Afro which she wears with confidence. Both Ndibe and Ifemelu capture the temporary duration of the pseudo-self and a quick return to the solid self. Many get trapped in this self and are unable to develop into a real self, having assertive beliefs. They are not as fortunate as Ifemelu as shown above, and Ndibe whom we shall depict shortly as an Afropolitan who can transform his pseudo-self into a solid identity of unmatched love for Nigeria, which supersedes his affection for America.

Unlike the pseudo-self, Kerr argues that an individual could be considered of solid-self if such individual holds firm convictions and beliefs about his identity. His views about his heritage and root are well-grounded and neither coercion, persuasion nor pressure can change his identity, belief, and self. He does not experience constant episodes of self-doubt and inferiority complex which leads to a pseudo-self (Kerr 1988:47). Such persons are governed by the intellect; not reactive to need, emotion and want. They can participate in highly emotional situations, knowing they can extricate themselves with logical reasoning when the need arises.

Reading Ndibe's story carefully, many episodes that describe Ndibe as an Afropolitan with solid-self easily jump to mind. Of all episodes, one such that we shall interpret for the obvious reasons of its caricaturist nature and underlining message is Ndibe's arrest at the bus station in Amherst, Massachusetts. In the chapter, Fitting the Description, the narrator retells his encounter with the police while waiting for a bus at Amherst. He describes how he was profiled and wrongly arrested in public view by a police officer for fitting the description of a bank robbery suspect:

I don't remember the trigger ... My eyes met the stare of a police officer waiting in his cruiser. The instant 
our eyes met, I remembered my uncle's warning: Americans did not stand for somebody looking them in the eyes. And here I was, looking a police officer deadon in the face... "Sir, do you mind stepping out to the back of the bus stop?" I heard the officer say... "Sir, you know what this is about, right?" he asked. I knew. Of course, I knew. I knew exactly what I have done to wrong this officer... I had committed the most unAmerican of acts: I had looked him in the eyes! And I knew better. My uncle had duly warned me... But the last thing I was going to do was confess... Denial was my only option... "No, I don't know what this is about."..."There has been a bank robbery," the officer said. "You fit the description." It was as if the earth beneath me had suddenly shifted, left me doddering. I was aware that everybody at the bus stop had turned, gazing at me, eavesdropping... I told the officer I had been in America only thirteen days, I had not been inside any American bank, I was in town to edit an international magazine... "Sir, do you mind if I frisk you...?" "No," I offered.... Convinced I had no weapon, the officer relaxed. "Do you mind if I drive you to your residence?" he asked. "I'd like to see your passport."... Several minutes later, he gave me back the passport. "Thanks for being a gentleman," he said. As he turned to leave, I remembered that many people had seen him question me, searched me, zoom away with me in the back of the cruiser. For sure, any of these spectators, whenever they saw me in town, could 
point me out to their friends and say, "This guy here is some kind of criminal... I saw the cop pick him up."... "Do you mind dropping me back off at the bus stop?" I asked the officer. It was a tactical move. I figured that other people would be there at the bus stop to see me step out of the cruiser and wave my thanks as the officer drove away. At the very least, when somebody pointed to me and said, "There's a criminal there. I saw him get arrested at a bus stop," chances would be that another witness would testify, "But I saw an officer drop him off at the same spot." "No problem at all," the officer said (Ndibe 2017:71-78).

This hilarious but racial encounter between Ndibe and the police officer captures many recurring tenets of an Afropolitan with solid-self. Ndibe who is barely thirteen days in America had begun witnessing stiff challenges and tests on his identity. In the end, he proves that he is governed by his intellect and not by his emotions or the need to be utterly courteous to gain quick acceptance in America. Having been cleared of the false accusation, he requested a reparation of his prestige and self by demanding a drop-off by the same police car to the exact location where he was picked up, as a sign of an open declaration of his innocence and the re-assertion of his identity and self. Such an act by Ndibe is proof that he considers his prestige and self of great importance and understands the value of the self, especially as an African immigrant. This can also be said about Adichie's Ifemelu in Americana who, on every occasion, challenges distorted views of her root and heritage and is not swayed by her emotion and the need for acceptance in America. Afropolitans with solid-self may experience periods of laxness in which they permit the automatic pilot of the emotional system to 
take full control because they are humans with emotions, as is the case with Ndibe, but when trouble and the need to define self develops, they can take over, calm the anxiety, and avoid life crisis. Ndibe's calm response and handling of the arrest situation are a testament to this. Because he is human, he got nervous at the beginning of the arrest situation but soon allowed his intellect to take charge of the situation which restored his dignity and selfworth.

When Stuart Hall argues that 'cultural identity is a social product which is never complete, always in process and strictly based on the positioning of the migrant', there is every possibility he was referring to the pseudo-self, not the solid-self (Hall 1994:401). The pseudo-self is in constant metamorphosis as his needs and wants change. This is the idea of what Stuart calls "cultural positioning", a period when a migrant identifies with a belief system that shapes his daily conduct as a result of his desires, needs, and wants. Identity for the pseudo-self is relational and 'based on the individual's perception and position at a particular time in history (Eze 2014:235). An Afropolitan with a pseudo-self has an incomplete cultural identity. He is swayed by his opinions, perceptions, emotions, and desires, unlike the solid-self that is fixed, stable, and rooted in the worldview of his root culture. Identity for the solid-self is no doubt completely shaped by his heritage, root, and culture.

In both analyses of the self, it is clear that whilst the solid-self advocates a return to the root, that is, an understanding of the self, based on one's ascribed identity which is static, permanent, and non-evolving, the pseudo-self is strictly in support of routing, a 
period when a migrant sees his identity from the lenses of his host country. Our argument, therefore, is that the process of routing cannot erase the root. In fact, what is routing without root? Or what has acquired identity without ascribed identity? Ndibe's narrative has shown that rooting presents a better self than routing. It provides one with solid identity and self as well as the need to value and protect such self and identity. However, we do not contend that routing or pseudo-self is wrong. What we push forward is a return to root despite routing. In migrating and routing which encourages a pseudo-self because of the need for acceptance, the Afropolitan should remember that one significant way to refine and transpose the self from pseudo to solid is to return to the African root.

\section{Space and Place}

The perception and relationship of space (the migration gap between the local and the global) and place (the understanding of the heritage and ascribed locale of the African migrant) is our focus here. This paper's interpretation of Afropolitanism does not intend to discourage young vibrant Africans from migrating to the Americas and Europe in search of better education and to advance their economic circumstances. After all, migration is a constant phenomenon practiced by all humans. James Clifford argues in support that 'everyone more or less permanently is in transit ...' (Clifford 1992: 109). What we contend is that, whilst in transit or routing, the Afropolitan needs to constantly embrace his African root and heritage to define himself. It is in the recognition, embrace, and acceptance of the African root that an Afropolitan can know who he is, where he is from, and chart a course that will enable him to navigate through the trauma of self-definition in the strange land he finds himself. Can one build a self or identity on 
nothing, no-root or 'no-self'? Can one be rootless? We can attempt to answer these questions more loosely from the perspective of Achebe when he argues that, for one to know when his body dried, one must first know when the rain began to beat him. To transpose this therefore could mean, for one to know who he is or what kind of self to espouse, one must first know where his root lies. Our reading of the Afropolitan journey in this way challenges Clifford's who argues that, whilst 'everyone more or less is in permanent transit, ... the question for them is not so much "where are you from?" but "where are you between?", (Clifford 1992:110). Clifford's contention has far-reaching fundamental flaws, for he has limited and reduced the arguments on culture and migration discourse to a single paradigm of space, whilst systematically obliterating the value and importance of place. Place, as discussed earlier, is crucial in migratory discourse and should be given critical attention. Going by Clifford's argument, how can one understand and appreciate his in-betweenness and space without acknowledging his place? We find this problematic.

Responding to the question above, Rico Lie (2002) proposes a third location beyond place and space which corroborates our argument for a return to the African place, as a third and final location. Lie argues that migration and culture should be conceived as a triangular discourse: from the local to the global and back to the local (Lie 2002:14). Although Lie does not say at what stage in the global should a migrant return to the local, we think such return should be done imminently, not until the self in the global has been completely broken. It is only when such a return journey or movement is made that the self and identity of the Afropolitan can be fully reconstructed. 
By the 'return to the African place or root', we do not mean a physical journey back to Africa- although that could be another possibility, as in the case of Ifemelu in Americana who eventually left America (space) and returned to Nigeria (her place)- but an epistemic mental journey. It is the re-rooting of the mind, the self, and the subconscious back to Africa. Hence, an Afropolitan can be in the American space and remain in the Nigerian place. Whilst in America, he thinks and acts Nigerian through his dressing, food, speech, name, and other cultural facts that are local to Nigeria. In this way, such Afropolitan has fulfilled Michael De Certeau's submission that 'space is a practiced place' (De Certeau 1984:20). What this means is that space is lived place, thus through action and communication, places transform into spaces and spaces into places.

The 'return' as a symbolic reconstruction of the self is captured in Ndibe's narrative. Whilst in the American space, Ndibe returned to the Nigerian place through the adoption of his native Igbo language to repair his broken self and identity. In "Nigerian, Going Dutch", one of the chapters in his non-fiction, he had gone for lunch with Karen, and the episodes that followed, leaves him with an almost broken self:

"Have you eaten lunch?" Karen asked me. ... "No." "Why don't we go for lunch," she proposed. I smiled to indicate my eagerness.... Karen and I ordered sandwiches, soup, and a soda each. ... A moment later, the waitress leaned in between us and left a bill. "We have to go," Karen announced, pulling out her purse and simultaneously motioning toward the bill. ... I said, "Thank you." She ignored me ... Then she said, more emphatically, "We gotta go." ...I said, again, "Thank 
you." ... Then using her finger to underline the point, she said to me, "You owe four dollars and twenty-five centsplus tip." In an instant, my first meal with a "generous" American turned into a moment of cultural disorientation. I was meant to pay for a meal, even though she had suggested it... I felt too embarrassed to tell Karen that I had no money on me, and that I had presumed on her philanthropy... "I believe I left my money in Professor Nnaji's office," I lied to Karen. "Why don't you pay for both of us? Then we will return to Nnaji's office and I will give you my portion of the bill."... She paid, still seething, a closed look seizing her face. We walked back to Nnaji's office ... Nnaji's door was ajar and I was relieved to find him in his office. In Igbo, I asked if I could have a word with him.... "I'd like to borrow ten dollars," I said.... He obliged. The cash in my hand swept away the embarrassment I had felt at the restaurant. With a sudden boost to my confidence, I called Karen out. "In Nigeria," I said in a didactic tone, "when you invite somebody out to eat, you imply an offer to pay for their meal."... "Here's ten dollars. I'm paying for both of us today. But please don't ever invite me again to eat, unless you're willing to pay." ... I went back into Nnaji's office... I told him the drama at lunch. Nnaji laughed and laughed... he said, "My brother, you've just been exposed to what Americans call going dutch." "I'll continue to go Nigerian," I vowed. (Ndibe 2017:57-66) 
From this lengthy episode, it is clear that Ndibe's choice of Igbo, instead of English, was his clear strategy to reconstruct and protect his identity. It was his native Igbo language that saved him from embarrassment. By choosing the Igbo language, Ndibe has shown the importance of returning to one's place, despite the different spaces he may occupy at different times, and has proven that language is an important feature of cultural authenticity and resistance. It is a tool for the reconstruction of broken identities. Had he not returned to the Nigerian place, his identity would have been completely broken. Spoken Igbo, his 'root language', authenticates and binds him with Prof. Nnaji, his countryman, more than English. He knows that this is the only language through which he could re-create and rebuild his identity and self-pride.

Not only did Ndibe return to the Nigerian place through the Igbo language, his response to Karen: "“In Nigeria," ... "when you invite somebody out to eat, you imply an offer to pay for their meal" (Ndibe 2017:66), indicates tradition as a second tool. Tradition is what defines a man and binds him to his place, despite his occasioned routing expeditions. It is the means to demonstrate the continuity of selected phenomena with an African past that shapes the African person. Ndibe, through this episode, demonstrates his connection with the African tradition by returning to his natal culture and root. He, we argue, captures this episode in detail, with its nuances, to show the need to 'return' to the African root and to encourage other Afropolitan that one strategy to reconstruct their identity is the return to the African place. There is clear power in the Afropolitan's place and they are by this reading admonished to seek their heritage, not only in time of need and difficulty but at all times.

However clear our interpretation of Afropolitanism and identity construction might be, we are aware that a few Afropolitan 
critics might find this reading problematic. Some might argue that not all Afropolitans possess knowledge and capacity as others who were born and perhaps raised partly in Africa. To resolve this, we refer to Cecil Blake's argument on roots and routes. Blake argues that everyone has got cultural roots. He went on to categorize the African root into two: firstly, of those who were born and raised in Africa having first-hand knowledge of the African culture, and secondly, those who were not born in Africa, who haven't been to Africa but whose parents were born in Africa and are familiar with the African stories (Blake 1999:50).

It is worth noting that Selasi's concern is, to a large extent, on the Afropolitans of the second group: those who were not born in Africa and have never lived in Africa. It is based on this peculiar circumstance of this group of persons and their struggle to fit into Africa that She argues that these people are 'rootless, displaced and neither here nor there' (Selasi 2005:10). Because 'cultural identity can be constructed through memory, fantasy, narrative, and myth', storytelling and books on Africa can serve as effective re-rooting techniques (Hall 1994:398). Since the Afropolitans of the second category have African parents, guardians, or elders who have either visited Africa, lived in Africa, or are familiar with the African system, such persons have the tall responsibility to 're-root' these new generations of Afropolitans to Africa. Not just through stories and books on Africa, they can re-root the Afropolitans through African cuisines, languages, and dress styles. Ndibe acknowledges the power of re-rooting: 'but I know something even more potent and powerful: the grammar of values passed on to me by my parents- and passed down by all the ancestors before them' (Ndibe 2017:145). 


\section{The Gain-Gain Paradigm of Root and Route}

When humans embark on a routine expedition, one must stress that the perspective to conceive the relationship between root and route should be from the gain-gain paradigm, not a loss-gain approach. When Africans route and naturalize, they do not lose their root to gain a route. In fact, we shall argue from Ndibe's narrative that, rather than losing their root, routing provides a platform for the Afropolitans to hold firm views on their root and acquire knowledge on their route culture. Nothing is lost, rather, all is gained. His route does not erase his root.

In the episode, A Brand-New American, Ndibe argues passionately that routing cannot erase root. He questions the popular belief that routing erases root through the process of naturalization.

Immediately after his naturalization ceremony as an American, Ndibe calls his mother on the phone to inform her of his supposed success and achievement. Her reaction suggests that routing vitiates one from his root:

... "Why...? my mother no doubt feared that I had "unbecome" what I had been before- an Igbo, a Nigerian, and African ... that I renounce and abjure all allegiance to my natal country" (Ndibe 2017:142).

She, like others who share similar views, thinks that Ndibe's acceptance to be American means rejecting and losing his root and everything Nigeria. But is this truly the case? In a swift response, Ndibe counters such a notion by pushing forward the argument that naturalization or routing does not mean the obliteration of one's root culture but a double gain. He puts it so explicitly: 
In assuming American citizenship, I had not undertaken to vitiate who I was before. I had not consented to bleach my "Nigerianness" ... Naturalization has never demanded of me, in the everyday experience of being American, that I erase Nigeria to enter fully and wholesomely into the patrimony of my American identity ... naturalization is not a loss-gain dialectic but a gain-gain proposition. In me, Nigeria and the United States don't find a battleground. Instead, they find a new momentum, a harmonic hyphenation: I am a proud Nigerian American (Ndibe 2017:143).

Nothing is lost in routing, but all is gained. Ndibe retains his Nigerianness and acquires the 'American citizenship status'. $\mathrm{He}$ is, as he calls himself, a 'Nigerian-American', one who is aware of his permanent Nigerian identity, which is his root, and a new position as an 'American' as well. The questions then are: Is he an American? Can an Afropolitan become a full citizen of his host country? Can one's route identity stripe him off his root identity? The position of a dual citizen, as Ndibe sees himself, is in contention. Ndibe detailed his experience with an editor: '...the editor could not imagine me as quite truly American. For her, my oath of allegiance might as well be a nullity' (Ndibe 2017:146). The subtle message being passed by the editor to Ndibe is clear: that he is not an American but always Nigerian and cannot erase his Nigerianness. Naturalization no doubt does not obliterate one's root culture, nor does it mean total acceptance in the route culture. 


\section{Afropolitanism, Hybridity, and Cosmopolitanism}

Because the reading of Afropolitanism suggests a subtle link to cultural mix, 'many African families', Eze argues, 'are now increasingly multi-ethnic, multi-racial, transcultural; they are now polychromatic' (Eze 2014:235). Eze seems to collapse the Afropolitans as hybrids. Their identity, for him, is defined by what Wolfgang Von Goethe calls 'elective affinities', as a process of self-identification through intermixing of ethnicities and races (Von Goethe [1978] 2014:240). In this paper's judgment, the Afropolitan identity is reconstructed through the return to the African root and heritage. It is not achieved through intermixing, cultural hybridity, or elective affinity. Cultural mix and hybridity 'foment displacement, precarity and loss' of identity for the Afropolitan (Balakrishnan 2017:5). Rather than rekindling the Afropolitan identity, elective affinity further dislocates the Afropolitan by encouraging acculturation, occasioned by the need for acceptance in the host country, which jettisons the African culture. An Afropolitan is not necessarily a cultural hybrid. Hybrid cultures are mergers that combine past and present, local and translocal, space and place, and technospace (Main 2015:80). An Afropolitan has not merged his root culture with his route culture. He can connect to his ancestral root without any struggle or complication. If Afropolitanism was cultural mixing and hybridity, it then presupposes that the Afropolitan, having experienced a mix in culture, would find it difficult to locate, identify and differentiate his ancestral culture from the new culture. This is not the case for Ndibe in Never Look an American in the Eyes, Ifemelu in Americanah, and Julius in Open City.

Not only is Afropolitanism different from hybridity, but it is also antithetic to cosmopolitanism. Cultural cosmopolitanism, Adam Etinson contends, 'affirms our capacity as individuals to live 
well in the world by forming pastiche identities that draw from cultures' (Etinson 2010:27). What Etinson is suggesting is that an individual can draw from many cultures and become a citizen of the world. We argue and maintain that although the process of Afropolitanism exposes an Afropolitan to multiple cultures, the Afropoltan is always rooted in a single culture which is his root culture. He is a rigidly determined product of his African culture and irrevocably cast into his Africanness. Even despite rejecting their Africanness in a foreign land and accepting the culture of their host country, as some Afropolitans do, they are always cast back into their African culture by the people of the host nation. The editor's response to Ndibe's manuscript for his first novel, Arrow of Rain, despite having informed the editor that he was a naturalized American citizen is proof that the Afropolitans are always pushed back into their root culture:

"I must say I judge novels from outside the US with harder requirements because of Americans' general difficulty in picking up books from other cultures." ... this editor could not imagine me as quite truly American. For her, my oath of allegiance might as well be a nullity. My ritual of naturalization was in vain (Ndibe 2017:146).

What this editor has proven is that Afropolitans cannot be cosmopolitans; they are not citizens of the world but citizens of a particular place, Africa. Their culture cannot be 'exchanged, altered, translated, or combined in idiosyncratic configurations' (Etinson 2010:27). It is now established that, if the Afropolitan does not willingly return to the African place, he would be 
forcefully returned to his root. Hence, at all times, he should remember he is Afropolitan, not cosmopolitan, and adhere to the values and traditions of his African culture, not to conceive his African culture as an outmoded and impracticable system. Whilst cosmopolitanism suggests 'forms of belonging which [are] not local, yet not western', Afropolitanism differs from this, in that, it advocates sinewy affinity to the local culture, heritage, and root (Balakrishnan 2017:5). Although the idea of cosmopolitanism requires individual cultures to collaborate and integrate and in Waldron's opinion, to approach one's cultural traditions not as a brute and non-negotiable but as norms and practices funded by an array of reasons that are open to interrogation (Waldron 2000:232), the Afropolitan is willing and open to integrating with the new culture but with a strong hold to his African heritage.

\section{Conclusion}

What we have tried to do in this paper is not to present Afropolitanism as a nostalgic paradigm that disregards and jettisons other cultures that are not African. African identity, we contend, should not be conceived as an oppositional discourse, the 'us against them' narrative which was the position of the early African critics who were tasked with the restoration of African dignity and identity immediately after the strictures of colonialism. The identity of today's Africans who are constantly migrating out of Africa should be based on culture complementarity. By complementarity, we mean respect for other people's cultures and way of life and not wanting to become those people and erase one's root culture. Even while many Afropolitans conceive themselves wrongly as cosmopolitans, hybrids, and of hypercultural paradigms, this paper has sufficiently shown through the reading of the Afropolitan self, of space and place and the construction of root 
and routes, that they are always rooted to the African place and can construct and reconstruct their identity only through the knowledge of their root culture. The Afropolitans are aware that their experience is always hyphenated, that is, attached to many traditions in polychromatic and diverse ways, but they are by this paper informed that their identity is strictly rooted in their African heritage, not tied to multi-cultures. Their identity is tied to their root, bloodline, and skin color and not a function of choice and attitude.

Chike Mgbeadichie teaches Cultural Analysis and Critical Thinking at the School of Media and Communication, PanAtlantic University, Lagos, Nigeria.

Chike Okoye is a Professor of Poetry and Postcolonial Literatures in the Department of English, Nnamdi Azikiwe University, Awka, Nigeria. 


\section{References}

Achebe, C. 1978. 'The Role of the Writer in a New Nation'. African Writers on African Writing. G.D Killam (Ed.). London: Heinemann.

Akhuemokhan, S. 2014. The Revolutionary Character in the African Novel. Ibadan: Ibadan UP.

Balakrishnan, S. 2017. 'The Afropolitan Idea: New Perspectives on Cosmopolitanism in African Studies'. History Compass 15: $1-11$.

Blake, C. et al. 1999. Intercultural Communication: Roots and Routes. Chicago: Allyn and Bacon.

Clifford, J. 1992. 'Travelling Cultures'. Cultural Studies. New York: Routledge.

1997. Routes: Travel and Translation in the Late Twentieth Century. Boston: Harvard UP.

Dagnino, A. 2013. 'Global Mobility, Transcultural Literature, and Multiple Modes of Modernity', in Monica Junega and Joachim Kurtz (Eds), Transcultural Studies. Heidelberg: Heidelberg UP.

De Certeau, M. 1984. The Practice of Everyday Life. Berkeley: California UP.

Etinson, A. 2010. 'Cosmopolitanism: Cultural, Moral, and Political'. Sovereign Justice 11: 25-46.

Eze, C. 2014. 'Rethinking African Culture and Identity: The Afropolitan Model'. Journal of African Cultural Studies 26: 234-247.

Gecas, V. 1982. 'The Self-Concept'. Annual Review of Sociology 8: 1-33.

Gilroy, P. 1993. The Black Atlantic: Modernity and Double Consciousness. London: Verso. 
Hall, S. 1994. 'Cultural Identity and Diaspora', in W. Patrick and L. Chrisman (Eds), Colonial Discourse and Post-Colonial Theory. New York: Columbia UP.

Kerr, M. 1988. 'Chronic Anxiety and Defining a Self'. The Atlantic Monthly 9: 35-58.

Lie, R. 2002. Spaces of Intercultural Communication. Barcelona: IAMCR Hampton.

Main, K. 2015. 'Placemaking in a Translocal Receiving Community: The Relevance of the Place to Identity and Agency'. Urban Studies 52: 71-86.

Mbembe, A. 2002. 'African Modes of Self-Writing'. Public Culture 14: 239-273.

2007. 'Afropolitanism', in S. Njami and L. Durán (eds), Africa Remix: Contemporary Art of a Continent. Johannesburg: Jacana Media.

Ndibe, O. 2017. Never Look an American in the Eye. Ibadan: Bookcraft.

Okoye, C. 2017. 'Transculturalism and the Ontological Spokesperson: Walt Whitman and Okot p'Bitek'. Okike: An African Journal of New Writing. 56.1: 59-71.

Onghena, Y. 2014. 'Transculturalism and Relation Identity'. Quaderns de la Mediterrania10. Eds. IEMed/Icaria Editorial. Barcelona: IEMed. 181-184.

Safran, W. 1991. 'Diasporas in Modern Societies: Myths of Homeland and Return'. Diaspora: A Journal of Transnational Studies. 1: 83-99.

Selasi, T. 2005. 'Bye-Bye Babar', in The Lip. http://thelip.robertsharp.co.uk/?p=76 
Waldron, J. 2000. 'What is Cosmopolitanism?'. The Journal of Political Philosophy. 8: 227-243.

Wawrzinek J. and Makokha J.K.S. (eds). 2010. Negotiating Afropolitanism: Essays on Borders and Spaces in Contemporary African Literature and Folklore. Amsterdam: Rodopi.

Yazdiha, H. 2010. Conceptualizing Hybridity: Deconstructing Boundaries through The Hybrid Formations. Formation, the Graduate Center Journal for Social Research. http://ojs.gc.cuny.edu/index.php/formations/article/view/6 $\underline{73 / 864}$ 